\title{
The Triumphal Entry in Sixteenth-Century France
}

\author{
V.E. GRAHAM
}

The triumphal entry in sixteenth-century France forms part of a very long tradition that dates back to the Middle Ages and continues, with interruptions, right into the nineteenth century. ${ }^{1}$ The early royal entries into Paris and other cities in the French provinces up to the end of the fifteenth century have already been carefully documented by Bernard Guenée and Françoise Lehoux. ${ }^{2}$ By that date the form of the ceremony was well established and the word "triumphal" was beginning to be used in the great variety of ways one finds in the century following, where it came to be applied not only to entries but to coronations, weddings, funerals, masses, buildings and even to costume. The only similar descriptive term equally common at the time and equally vague in its import is the appelation "à l'antique."

Both expressions evoke classical models, to be sure, and one might well ask how much was then actually known concerning Roman triumphs and other customs they were supposedly imitating. This no doubt varied considerably, depending on the commentators, but, as early as 1517 , for the entry of Francis I into Rouen, one of the decorations consisted of a huge horse with its front feet up in the air and on its back a figure representing the king. The account of the entry notes that this statue

avoit esté ordonné pour... emuler le triomphe des romains, desquelz à leurs consulz, imperateurs ou autres hommes vertueulx, qui avoient fait chose digne de memoire à l'utilité de la chose publique, erigoyent en lieu patent à Rome une statue de marbre ou cuyvre pour perpetuelle memoire de celuy qui estoit digne de triumphe.

Royal entries into Rouen differed from those in other parts of the kingdom in that they regularly involved the use of triumphal chariots, somewhat like modern-day floats, rather than just stationary decorations. For the entry of Henry II into that city in mid-century, we find the following statement concerning their purpose: 
faisantz le parfait du magnifique triumphe que la ville de Rouen vouloit exhibiter à la majesté de son Roy, non par simulacres ou platte peinture, mais par l'effect des choses vives et mouvantes, à l'imitation expresse des Romains triumphateurs.

And as for triumphal arches, the account of Henry II's entry into Lyon noted specifically that one of the arches constructed for that occasion was “autant belle que tout l'edifice esgalloit en beauté d'architecture à tous les arcz qui aujourd'huy nous restent de tant d'excellentz monumentz et reliques de la gloire des Romains."

Be that as it may, the basic problem facing anyone wishing to study ceremonial entries is their ephemeral character. The various triumphal arches with statues, inscriptions and bas-reliefs, as well as other elaborate monuments such as fountains flowing with wine, colossi, pyramids, columns, and obelisks, were all made of wood, painted canvas and plaster, skilfully moulded and coloured so as to simulate marble. (Fig. 1) These were the "simulacres ou platte peinture" disparagingly referred to in the account of the Rouen entry of 1550 . Such decorations were systematically dismantled right after the ceremony, and the only potential sources of information remaining are the commemorative albums frequently published to mark the event, some of which were illustrated with woodcuts, the notarized drawings prepared for the guidance of those responsible for executing the decorations, where these exist, and civic account books detailing expenditures of various kinds. These in turn can sometimes be controlled by informal descriptions provided by eye-witnesses, but the formulary language used in the documents in particular, makes it very difficult to reconstitute with any degree of assurance what actually took place, as McAllister Johnson has demonstrated in a paper published in the third volume of Les Fêtes de la Renaissance. ${ }^{3}$

The first question a skeptical critic might be tempted to ask is, why bother? Actually, there are many more answers to such a hypothetical question than might at first appear. Since triumphal entries into large cities were unique festive occasions costing enormous sums of money, the City Fathers regularly enlisted the aid of the most celebrated poets, painters and sculptors to help co-ordinate the decorations. These artists invariably formed part of the establishment, rather than the avant-garde, and this aspect of their creative activities is generally not at all well known. Thus for the Paris entry of Henry II, the City Council did not call on the bright young members of the Pléiade or the artists who were soon to become known as the School of Fontainebleau. Instead, they turned to the translator Jean Martin, the reactionary poet Thomas Sebillet, and the wellknown artists Jean Goujon and Jean Cousin. By 1571, however, for the entry of Charles IX, they were ready to commission the now official court 
Renaissance et Réforme / 239

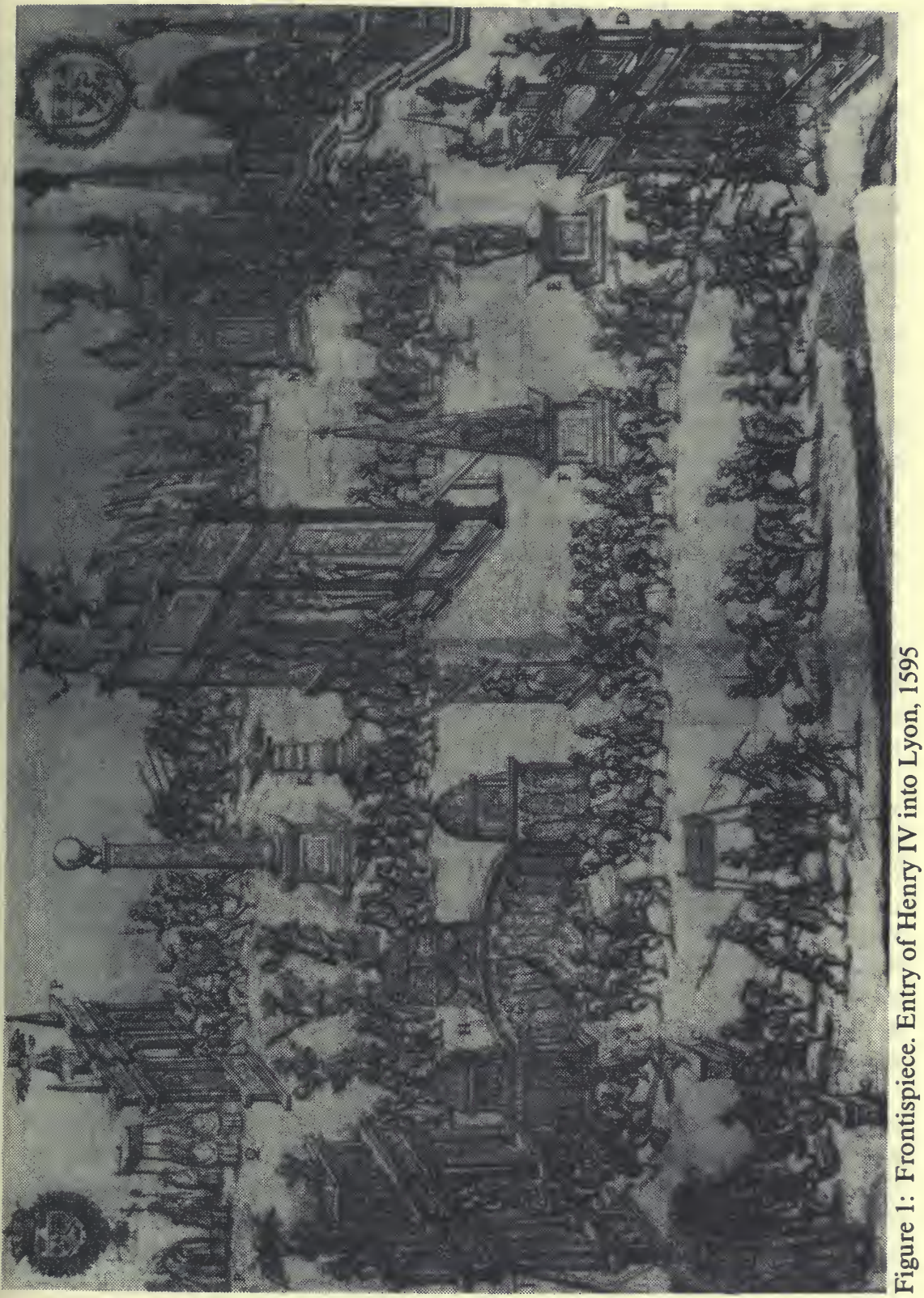


poets, Ronsard and Dorat, to help plan the entry and compose inscriptions in French, Latin and Greek, while the Fontainebleau painter, Nicolò dell'Abate, along with his son and the sculptor, Germain Pilon, were entrusted with executing the decorations.

In their evolution, the indicators of taste provided by such interdisciplinary collaborations are important clues to the development of Humanism during the century, as well as the variable influence of such key sources as the Scriptures, Classical mythology, the Hypnerotomachia and the Emblems of Alciati. George Kernodle, in his seminal work, From Art to Theatre, has shown the close connection that exists between the classical stage with its proscenium arch and the dramatisations associated with the triumphal arches in sixteenth-century entries in particular. ${ }^{4}$

Early in the century the French painter Geoffroy Tory had used architectural elements as ornaments in an entry book, initiating a trend which saw the application of stylized triumphal arches to decorative frames for the title pages of all kinds of books. And finally, tombs in churches, whether free-standing for royal personnages, or placed against a wall for nobles of lesser rank, also gradually adopted the form and symbolism of the triumphal arch.

The honour of a triumphal entry was normally reserved for the King when he formally entered a city for the first time after his coronation. An entry, by definition, was into a walled city, and the three most important centres in France which vied with each other in the magnificence of their spectacles were Paris, Lyon and Rouen.

The King was always met at the main city gate by civic representatives who reaffirmed their loyalty to him as their sovereign and presented him with what, at the time, were the actual keys to that particular gate. The purpose, as we are told in the account of Henry II's entry into Rouen was "par ces moyens attirer la faveur et benevolence d'iccelluy." When the King had heard the official "harangue" or "oraison," as it was sometimes called, which was read by the provost or mayor kneeling bareheaded, he then would respond in kind, and, after returning the keys, would take his place at the end of the official procession, however long it might be, following the traditional route to the cathedral. Here there would be a similar exchange of pledges with respect to the Faith between the Bishop or the Dean of the cathedral and the King who would kiss the Bible or holy relics before entering the church for prayers and the singing of the Te Deum, using the central portal which was opened only for the most solemn occasions. This symoblic entry into the spiritual kingdom paralleled in a sense the earlier entry into the material realm through the city gate which had been temporarily transformed for the King's benefit into a triumphal arch.

The link between the two was provided by the canopy or "poelle" (from the Latin "pallium") which was held aloft on four or sometimes six 
supporting poles carried by the city's most distinguished citizens. (Fig. 2) This "poelle" or "ciel" as it is sometimes called, was placed over the King's head as he entered the city on horseback and removed only when he dismounted at the entrance to the cathedral. A fixed ceremonial canopy or dais had long been used above the King's chair indoors and over pulpits and niches for statues in churches, but Guenée and Lehoux argue in favour of tracing the origins of the portable canopy to the "poelle" or "ciel" which provided an extension of the sanctuary when the Host or the holy oil used in the coronation ceremony were transported with an escort out-ofdoors.

In Roman triumphs the conqueror-hero and, later, the emperor alone had been assimilated to Jupiter, and in France the King, as God's annointed, was thought to take the place of the Blessed Sacrament which was always carried in procession with a similar canopy over it at the Feast of Corpus Christi. This is made quite explicit in the description of the entry of Francis I into Lyon when the City Fathers received the King

qui, dès lors, comme Dieu, un jour de grande fête, va marcher sous un dais merveilleusement brodé, précédé de lourdes croix, de bénétiers, d'encensoirs, d'argent et d'or.

In the same city, for the entry of Henry IV at the end of the century, the Dean of the cathedral addressed the King as follows:

Nous vous avouons pour nostre Roy, et vous recognoissons pour la vive image de Dieu, représentant parmy nous sa Majesté éternelle.

In this context the public fountains flowing with wine could be thought to symbolize a kind of civic communion glorifying the sovereign as God incarnate.

It was also common practice for triumphal entries to be accorded to the King's consort, to other members of the royal family and to royal visitors such as Henry VIII of England and the Emperor Charles V when the King specifically requested it. Sometimes entries by the King and his Queen would take place on successive days if they were on tour in the provinces, but occasionally they were widely separated. The kings of France were traditionally crowned at Reims, after a triumphal entry into that city, but the queens were crowned at the Abbey of St. Denis, just north of Paris. Often their entry into the capital would take place shortly after their coronation. This was the case with Henry II's wife, Catherine de' Medici, and with Charles IX's wife, Elisabeth of Austria. The same sequence was planned for Marie de' Medici, the wife of Henry IV, even though her coronation took place after ten years of marriage and six children, at a time when Henry IV wished to legalize her status as a possible regent. The coronation 
Portraict de HENRY IIII Roy de

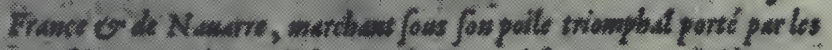

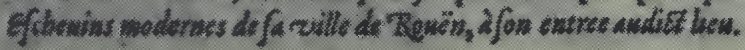

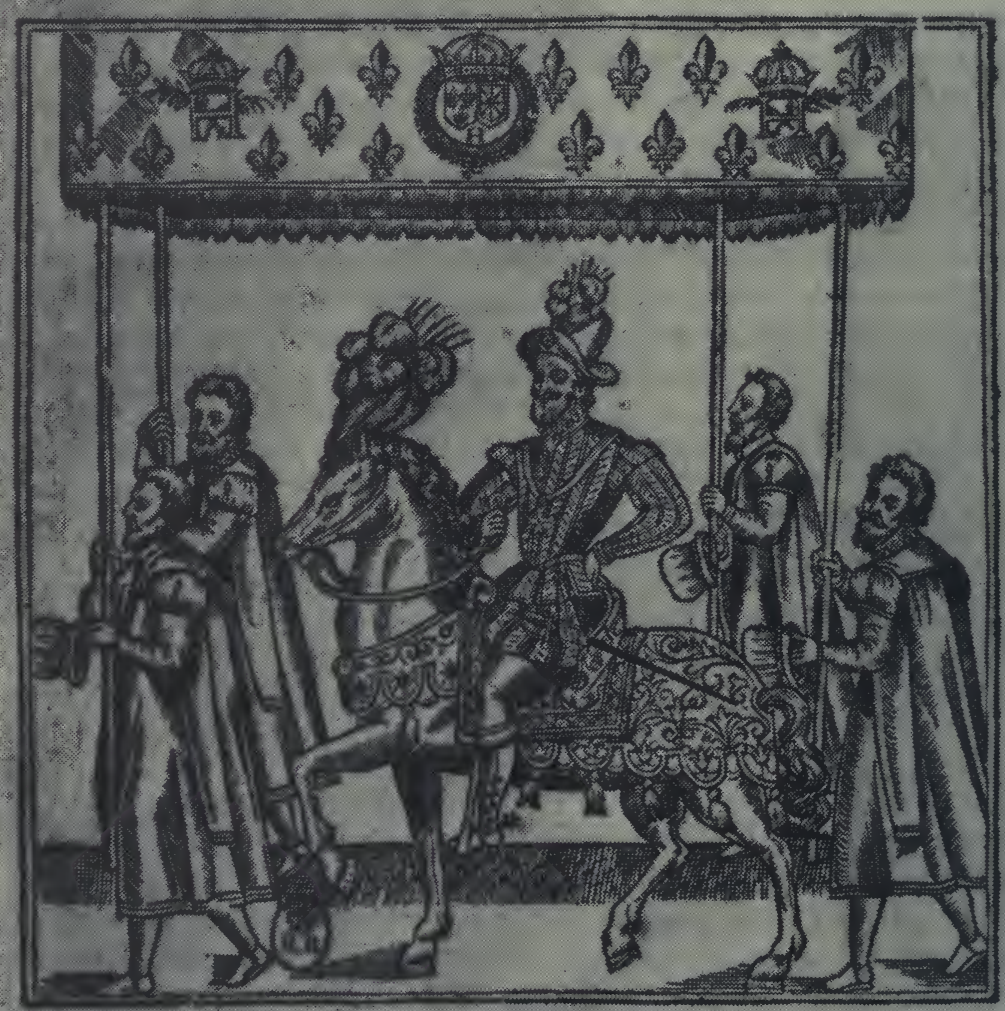

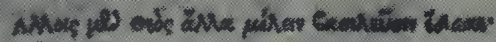

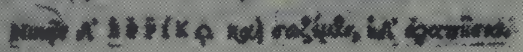

pisig. 
went ahead as scheduled on May 13, 1610 but the entry, which was to follow a few days later, had to be cancelled when Henry IV, out riding in his coach the day after the coronation, was stabbed to death by a malcontent.

By extension, a triumphal entry was also usually accorded in the provinces to governors representing the King when they first assumed their functions, and to Papal Legates and newly appointed Bishops, as representatives of the Supreme Pontiff. In these cases there were sometimes arguments about the propriety of providing the canopy or "poelle" which was the highest possible mark of honour. In Paris, for example, for the entry of the Papal Legate in 1530, the City Fathers agreed that the "poelle" could be carried by representatives of the merchant guilds but not by the City Comptrollers, "parce que cy devant cela ne se trouve avoir esté faict, et aussi que pour l'Entrée du Roy l'on ne pourroit faire davantage." At Lyon in 1533, where the Dauphin and the Papal Legate were to make entries the day before and the day after that of Queen Ellenore, the second wife of Francis I, it was decided not to provide a "poelle" for the Papal Legate who then refused to participate, even though the description of the three ceremonies was in the process of being printed as though they had already taken place.

The demands of precedent and protocol were paramount, not only in the context of the royal entry in general, but in terms of what had been done in any particular city in the past. Nîmes was exceptional, in that the City Fathers had put up a permanent monument in the form of a stone column surmounted by a salamandar made of lead to commemorate the entry of Francis I. They wanted to do the same sort of thing for Charles IX but had to abandon the idea when there was insufficient time to undertake construction. And at Macon, when it was known that Charles IX was to visit that city in June 1564, a frantic search failed to turn up any of the documents concerning Henry II's earlier entry, so that the local council was obliged to organize an entry unrelated to precedent. In 1595, however, when Henry IV visited the city, plans for his entry were based on what had been devised for Charles IX thirty years earlier.

The first matter to be regulated, of course, was the route to be followed. Wherever possible, the elaborate covered reviewing stand with a special chair for the King was set up at an abbey or convent just outside the city gates. In the case of Paris, this was traditionally at the Priory of St. Lazare, just beyond the Porte St. Denis which gave access to the rue St. Denis, the principal commercial artery leading into the city from the north and one of its few relatively straight roads, since it had earlier been an ancient Roman thoroughfare. It was also the route which St. Denis, the patron saint of the city, is supposed to have followed after his martyrdom when he miraculously carried his decapitated head under his arm as far as the site of the 
future abbey of St. Denis, which was also the traditional location of the tombs of the French kings. Ralph Giesey, in a book on the royal funerary ceremony in sixteenth-century France, has provided a fascinating study of the similarly elaborate ceremonies that marked a king's death, and his triumphal return back up the same route that had led him into the city on the occasion of his first formal entry. ${ }^{5}$

The processional route for triumphal entries into Paris began, then, at the Porte St. Denis, following the rue St. Denis down to the Seine where it ended abruptly at the Chatelet. Here it was customary to mount a large illusionistic painting, some thirty feet high and forty feet wide, to conceal the river and the view beyond. At this point, however, the procession turned left in order to proceed to the Pont Nostre Dame which led across the river to the cathedral. This bridge had houses on both sides of it, much like the Ponte Vecchio in Florence today, and here it was customary to place arches at each end of the bridge with a kind of roof of greenery overhead from which hung various ciphers and coats-of-arms.

At Lyon, the processional route ran along the north bank of the Saone from the main gate down to the Cathedral of St. Jean which was the cathedral church of the see of the Primate of France. This was the route followed by all of the kings in the sixteenth century with the exception of Henry III who had gone to Warsaw after his election as King of Poland in 1573. When he received news of the death of his brother, Charles IX, early the following year, he immediately set out on the return journey to France, detouring via Italy on the way. Since he was to enter Lyon from the south, rather than the north, a different route was used which required the construction of a special temporary bridge over the Rhône.

The organization of a triumphal entry required a tremendous effort and involved the participation of a vast number of people if it was to be done on the scale characteristic of the principal cities in France. In order to finance the considerable expenditures, many substantial loans at high rates of interest were arranged with wealthy citizens, members of the nobility and the heads of religious congregations. Ordinary citizens, who naturally tended to resent the levies imposed on them, were summoned by the town criers to appear for the ceremony on pain of stiff fines or other punishment. And when they did, as one learns from the account books for Charles IX's entry into Paris, the constabulary were out in force, equipped with 1,500 matraques or police billies to keep spectators under control along the route. It is not at all unusual to read in the different chronicles that some spectators were crushed to death in the crowd or that a few soldiers, in their armour, died from suffocation.

One of the common features of royal entries was the very visible presence of the militia, with companies of foot-soldiers and mounted units incorporated into the procession. Some of them also were involved in 
providing appropriate military salutes as the King arrived at the city gates. In Paris and Lyon, this required transporting cannons from the central arsenal to the bulwarks outside the city wall, while at seaports such as Bordeaux, the guns would fire from vessels in the harbour, since the king usually arrived there by water. And it was not just a case of a 21 -gun salute, since the narrative accounts often mention that the salvoes lasted anywhere from half an hour to an hour, and at Caen, for the entry of the Dauphin in 1532, there were no fewer than 120 pieces of artillery firing simultaneously.

All the church bells would be rung, too, and as the King entered the city gates, there would be a fanfare of trumpets. If smaller cities could not provide these, along with fifes and drums, they would be imported from a larger centre. Music was regularly played at the location of the different monuments along the processional route and the streets were also sanded and strewn with flowers if the season was appropriate. Citizens who had houses on the official route were required to hang tapestries from their windows and groups of young children were co-opted to shout "Vive le Roy" and "Noël" as the king arrived at each successive monument.

One might well wonder why the word "Noël" should be used under such circumstances. A possible explanation that might suggest itself is that it was simply an exclamation of festive exuberance, such as "Alleluia" or "Hurrah!" because it would seem highly unlikely that any conscious identification would be made between "Noël", which comes from the Latin "natalem" referring to the birth of Jesus, and the presence of the King as God's annointed. A more plausible explanation, however, is provided by the traditional French coronation ceremony where the King was acclaimed after the actual crowning, not with the Latin "Vivat" but with the French "Vive le Roy-Noël. Vive le Roy." Here the mythology, like so many French royal traditions, is evidently derived from the coronation of Clovis, the first of the recorded kings of France.

Clovis was a pagan converted to Catholicism by St. Rémy after a miraculous victory over his enemies. He is supposed to have pledged, under pressure from his wife who was already a Christian, that he would join the church if he were victorious in a crucial battle. His conquest was assured when a mysterious white stag came out of the woods to indicate a ford in the river at the only possible spot where his troops could make a crossing in order to surprise their adversaries.

A number of other miracles traditionally associated with the baptism of Clovis which took place on Christmas Eve and his coronation at Reims which took place on Christmas Day are shown in one of the decorations for the entry of Francis I into Lyon in 1515. (Fig. 3) There was said to be such a crowd around the baptistry that the priest carrying the holy oil could not get through to St. Rémy who was very perplexed as to what to do. 


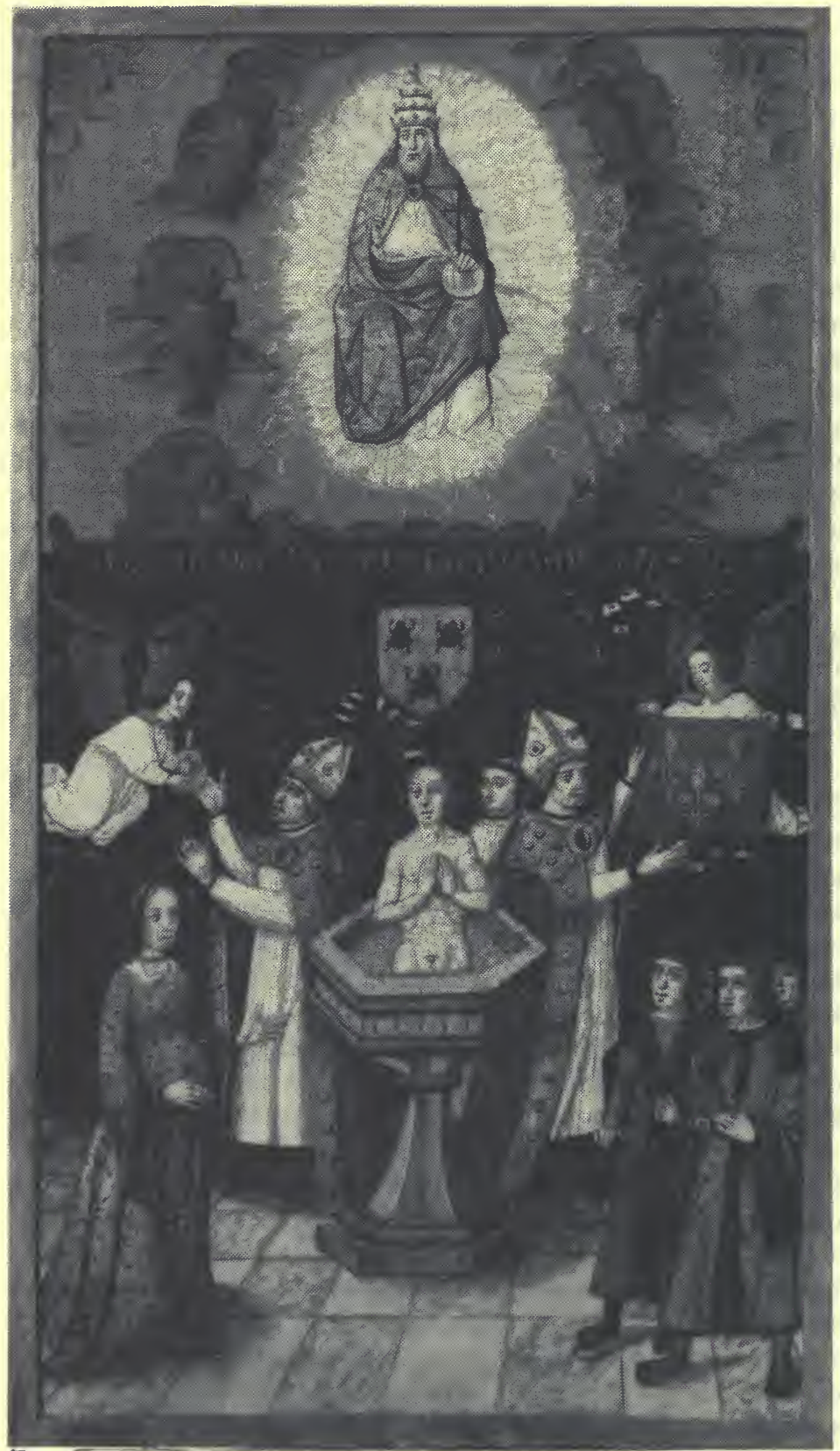

Figure 3: Entry of Francis I into Lyon, 1515. Baptism of Clovis 
As he raised his eyes to Heaven in supplication, a white dove is supposed to have descended from on high carrying in its beak the Sainte Ampoule, a precious flacon containing a miraculous ointment which, after its use on this occasion, was then carefully preserved for all subsequent coronations.

There were two other miracles that also form part of the legend. One was the supposed transformation of Clovis's coat-of-arms which had consisted of three toads into the three golden fleur-de-lis. The actual origin of the fleur-de-lis is shrouded in mystery, but since it was not used before the twelfth century, it could not possibly have been associated with Clovis, even indirectly. Its form, which is very like the point of a halberd, may have been derived from the ornamental fleuron on the royal sceptre which ressembled a stylized iris. Similar ornaments were used on the open crown that French kings wore until about the middle of the sixteenth century when it was officially replaced by the closed, imperial crown. For Henry II's entry into Paris in 1549, one of the arches had two angels on the top supporting such a crown because, as the text explains, "le Roy des Français ne recognoist aucun superieur en terre [mais] est monarque en son pays qu'il ne tient sinon de Dieu et de l'Espée.'

Charlemagne was also crowned on Christmas Day, and some of the appurtenances of majesty associated with the Kings of France were supposed to derive from that ceremony. They included the great crown, a lesser crown the King put on after the actual ceremony of coronation, the sceptre and the main de justice, a golden rod surmounted by a hand. Such a symbol in the gesture of the "Ave!" or "Hail, Caesar!" had been used in imperial processions by the Romans. Claude Paradin in his Devises héroiques (Paris, 1622) illustrates the form but the main de justice of the kings of France was carved from ivory in the gesture of the logos, i.e. with the thumb and first two fingers straight and the other two bent. This is the speech gesture of antiquity, later adapted to the ritual of pronouncing the benediction in the Catholic church. Some commentators have also seen in the ivory of an elephant tusk a further allusion to religion and wisdom since, iconographically, this is what the elephant always stood for. The earliest recorded representation of the main dejustice dates from the reign of Hugues Capet, almost two hundred years after Charlemagne. In the seals and medals of later kings, it is sometimes shown in the right hand, sometimes in the left, but the symbolism is meant to suggest that the temporal power represented by the scepter is proclaimed abroad by the logos of the main de justice.

The miraculous power of the outstretched hand of the king has been studied by H.P. L'Orange in a remarkable book called Studies in the Iconography of Cosmic Kingship in the Ancient World,${ }^{6}$ and the final miracle associated with Clovis may well be considered as an extension of that same concept. After his coronation by St. Rémy, Clovis is supposed to have had a 
dream in which he appeared to heal his favorite squire by putting his hand on his neck. The squire was suffering from scrofula and when Clovis repeated, in the presence of St. Rémy, the procedure that had seemed to be efficacious in his dream, the squire was instantly healed. He then used this extraordinary power throughout his life, and it was also theoretically transmitted to all his successors at the moment of their coronation. The Kings of England were supposed to have acquired it through Henry VI who was King of England and of France, and, as late as the nineteenth century, Charles X went through the formality of a rather unconvincing public ceremony involving the laying-on of hands. This particular phenomenon has been studied at length in another important book by Marc Bloch, Les Rois thaumaturges. ${ }^{7}$

Scrofula, or écrouelles as it is known in French, is a well-defined malady of the lymphatic system resulting from malnutrition. During the seventeenth century the King performed the ceremony of touching the sick only on set feast days - Easter, Pentecost, All Saints' Day, and Christmas Day, but in the sixteenth century the ceremony was regularly associated with formal entries, sometimes on the very same day but more often a day or two after. Victims of the disease would come from all over, and when Charles IX visited Bayonne, the chronicles record that "Le Roy toucha les malades des escrouelles d'Espagne." Sometimes there might be two or three hundred, but when Henry IV entered Rouen there were said to be well over a thousand. The ritual followed was for the King to make the sign of the cross with his outstretched right hand on the invalid's forehead while he repeated the formula "Le roi te touche et Dieu te guerit." The origins and the history of the custom are outlined in a Latin treatise, De Mirabili strumas ..., published in 1609 by André Du Laurens (Andrea Laurentio) who was Henry IV's physician.

Another traditional feature associated with the royal presence was to provide "largesse" for the assembled crowds. This was always done for coronations and weddings, and very often also for entries such as that of the Emperor Charles V into Paris in 1540. Bread was distributed to the poor but the mixture of coins of various denominations, including on occasion some that were specially minted, was generally scattered in the cathedral by the heralds to the cry of "Largesse, largesse." For the triumphal marriage of the Dauphin Francis and Mary Queen of Scots, the account records that when largesse was distributed, there was much shouting and pushing with

les assistans audict lieu [se] precipitans les uns sur les autres pour la cupidité d'en avoir. Les uns demeurerent evanouys, les autres perdirent leurs manteaux, les autres leurs bonnetz et autres habitz. 
Prisoners were also freed from jail but it is ironic to note that when Queen Ellenore and the Dauphin were scheduled to make their entry into Rouen in 1532, Francis I wrote to the Parlement in that city ordering them specifically to take four prisoners (three men and a woman) to another location so that they would not be included in the general amnesty.

The King, on the occasion of an entry, always received a gift from the city concerned. In earlier times his progress through the provinces required provisioning, with hay for the horses, wax torches for illumination at night, food and drink for the numerous company that went with him, and presents of wine, sweet-meats and money for the monarch, members of his family and some of his high officials. These functions continued at a basic level, of course, and when Charles IX visited Langeais, the citizens of that community, in a symbolic gesture, marched out to meet him in procession, each grasping a small handful of straw.

The gifts of coin or of objects made from silver or gold were of a value directly proportionate to the resources of the city. They were always the subject of negotiations between the City Fathers and the King's Chancellor, and what really mattered was the weight and monetary value, not the artistry displayed in manufacture. Such items could then readily be converted into cash and that is why literally none of them have survived. Sometimes the King would be given a vase full of gold medals specially struck for the occasion, as at Avignon in 1565, or an elaborate example of the goldsmith's art. The latter frequently incorporated coats-of-arms or allusions to the city in its special relationship with the King. Presents from Lyon, for example, always had a lion somewhere, supporting the King's arms or a column, and gifts from the city of Troyes in Champagne regularly evoked Hector and the Trojans from whom the French kings claimed to be descended.

Smaller centres sometimes ordered their gifts from Paris or Lyon, and what may seem somewhat startling, perhaps, is that the King quite regularly decided in advance which one of his nobles was to receive the present in question in recognition of his services. Then if the gift, for some reason or other, was especially pleasing to the King and he wished to keep it, he was obliged to reimburse the potential recipient in kind. At Narbonne, for instance, Charles IX was given

une clef d'or, pesant deux cens escus ou environ, fort bien elabourée, burinée et emaillée, avec les armes et devises de sa Majesté et celles de la ville au plus bas. Le Roy le trouva si belle qu'aprez l'avoir un long tems contemplé, il luy prit envie de la garder, et commanda qu'on donnât autant qu'elle pesait à celuy qui avoit eu en don le present de Narbonne.

In larger centres, commemorative medals or jetons were often struck as souvenir items for officials of various kinds. 
Other regular features associated with royal entries were an elaborate banquet and festive bonfires lit in the evening to help celebrate the occasion. These were called "feux de joie" or "feux d'allegresse." The account of the triumphs for the signing of the peace at Lyon in 1559 recall only too vividly the brutality and the violence so characteristic of the age, which is often overlooked in studies primarily oriented toward aesthetic content. For the entertainment of the spectators there,

Au devant des prisons Royaux ... fut elevé un posteau, garny de bois et de paille: et à la cyme dudict posteau y avoit deux chats en une cage, desquelz quand ils sentirent le feu, faisoit bon ouyr le chant et melodie.

For many entries there were also regional dances, bull-fights and jousts of various kinds. At Marseille, a regular feature of the entertainment consisted of mock battles using oranges. The tradition of having savages or wild men engage in scrimmages goes back at least to the fourteenth century and is found in centres as widely separated as Troyes and Bordeaux. One of the most celebrated examples that made a great impression at Henry II's entry into Rouen consisted of one hundred Brazilians plus some two hundred French, dressed - or rather undressed - to look like Brazilians and participate in a demonstration of native customs which included fierce fighting. There were also simulated naval battles on the rivers at centres such as Rouen and Lyon and at port cities like Bordeaux. It was none other than Rabelais who was responsible for organizing the Sciomachie or celebration with jousting and military displays given at Rome on the occasion of the birth of the Duc d'Orléans in 1550.

The most considerable items of expense in the account books connected with entries were not for decorations or for gifts, however, but for costumes. One must remember that the festivities were not just for the King and his entourage, but for the civic hierarchy who were also there to see and be seen. The members of the different merchant guilds, military companies, civic groups and the basoche were required to wear appropriate costumes, and the leaders who were to mount the official stand to pay hommage to the king all had their outfits paid for by the city. At Rouen in 1563, after the suppression of a revolt the previous year, many who were ordered to march in the procession on the occasion of the entry of Charlex IX "ne peurent marcher pour n'avoir assez de tailleurs pour faire leurs habitz."

As in all such processions, the lesser functionaries took their place near the front, with each succeeding group becoming more and more important. The earlier ones were on foot, presumably trudging through the sand, while the later ones were on horseback. These included, just before the members of the King's household, the wealthy bourgeois of the city and another group consisting of their sons up to the age of thirty who were 
called "Les Enfants de la ville." The latter elected from their number a captain whose position of honour singled him out for extra-special attention, and these elaborately-costumed individuals were often the subject of an illustration in the commemorative albums. No women ever participated in a King's entry, not even his consort, and for the Queen's entry, where the monarch in turn did not appear, the only other women present were the ladies of the court who rode in litters or carriages in the royal party.

There were many sumptuary laws on the books in France in the sixteenth century, but they do not seem to have been applied very strictly. In an ode addressed to Henry II in 1550 (V,ii), Ronsard wrote approvingly of his ordinance restricting the use of velvet and silk to those of higher rank, noting that

Le velours trop commun en France

Soubz toy reprend son vieil honneur,

Tellement que ta remonstrance

Nous a faict voir la difference

Du valet et de son Seigneur.

Men were also forbidden to wear cloth woven with threads of gold or silver but since the law in question did not at first apply to women, it was a very difficult one to administer. Crimson, which corresponded to the imperial purple of Roman times, was considered to be a royal prerogative, but Montaigne, writing later in the century in an essay entitled Des lois somptuaires (I, xliii), observed that the period of mourning after the death of Henry II (1550) was scarcely over when the use of brilliant silks woven with gold or silver became so common among doctors, surgeons and courtiers in general that "si vous en voyez quelqu'un vestu, vous en faisiez incontinent quelque homme de ville."

In the descriptions of costumes provided for those participating in triumphal entries, all restrictions seem to have been relaxed, though the King himself naturally wore the richest outfits, encrusted with jewels whose value was often cited or described as "inestimable." One interesting observation that can be made is that costumes on these occasions were invariably of the latest fashion and never classical or "à l'antique," despite the fact that the King was sometimes shown in illustrations with a laurel wreath on his brow.

When one turns to the decorations, the themes used throughout the century are seen to be infinitely complex. One could make a lengthy repertory of them under such general headings as History (either real or legendary), Allegory, the Bible and the Classics, beginning with the brief dramatizations that were presented at the different monuments or "théatres" along the processional route for the early entries. These involved the use of live 


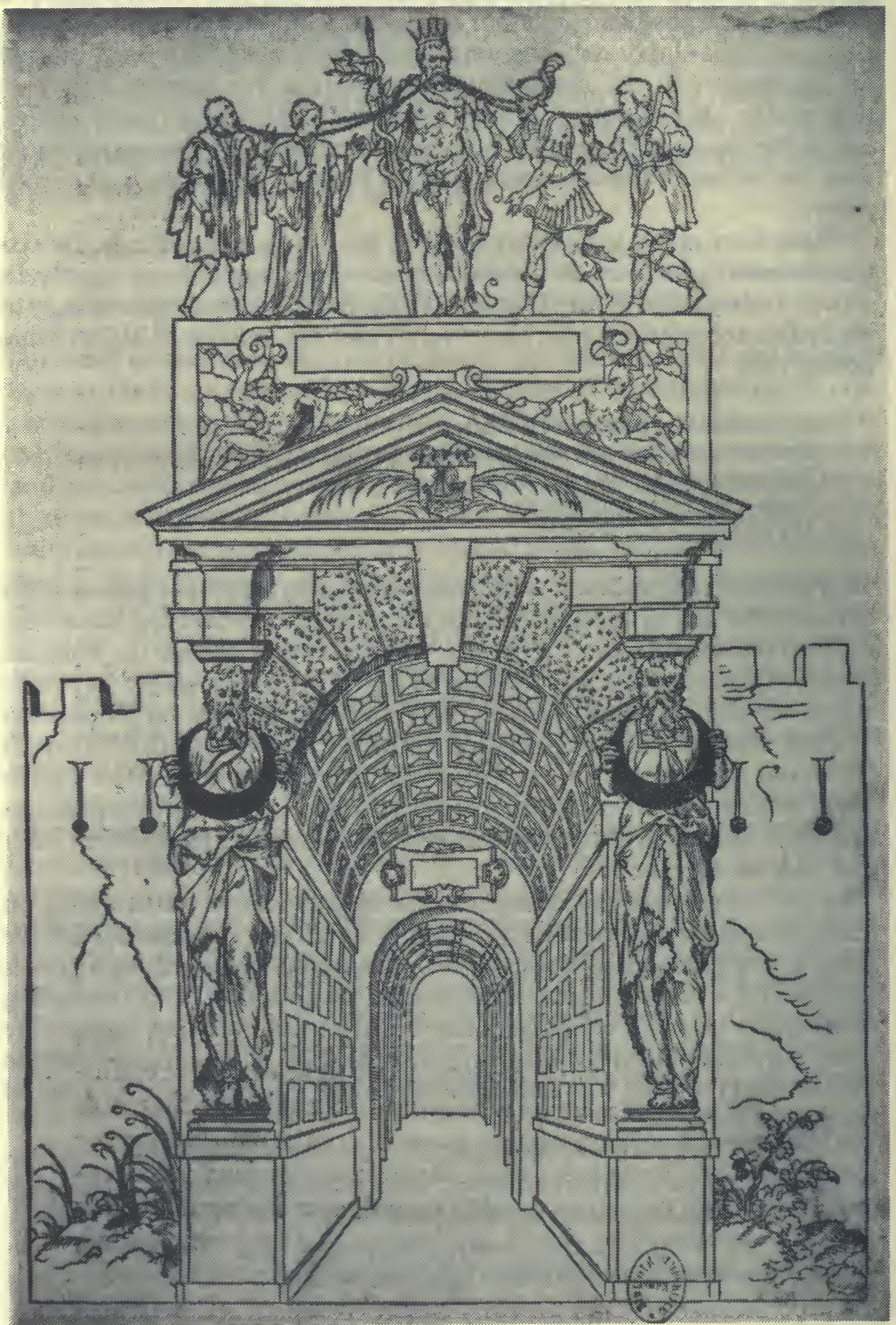

Figure 4: Entry of Henry II into Paris, 1549. Porte St. Denis 
actors who gave their performance only once for the benefit of the King as he arrived at that particular spot.

In Paris, however, statues were employed at a relatively early date to replace the live "figurants," and inscriptions in French or Latin were used to explain their import for all those who were able to read. Such decorations were usually constructed behind canvas screens, and they were kept under cover until the time of the entry, much like the ceremony of unveiling statues nowadays. But the totality of the ensemble could be appreciated afterwards by those walking along the processional route and each inscription, whether comprehensible or not, contributed to the general effect. As John Sparrow has pointed out in his book Visible Words or Inscriptions in and as Works of Art,

Besides pleasing the eyes of those who look on it, [an inscription] may at the same time affect their emotions, and it may do this even if they do not understand what it means: it can, by its assimilation, convey a sense of grandeur - a sense, usually, of "the grandeur that was Rome."

As far as triumphal entries are concerned, inscriptions both in French and in Latin date from the very beginning of the century, but Greek is used only selectively, first at Lyon in 1533, and then at other cosmopolitan centres later on.

On the other hand, decorations based on allegorical figures and the Bible were certainly more common in the early part of the century, but they continue throughout the entire period. A common feature in almost every city was an allegorical representation of its rivers - in Paris the Seine and the Marne, in Lyon the Rhône and the Saône. One could quote a long list of abstractions such as Concord, Majesty, Honour, Victory, Faith, Justice, Fame and Religion which were always represented as female figures with identifying attributes. Blind Justice with her sword and scales is probably the one best known to us, but the lost language of symbolism was common currency at the time, even though some observers, including occasionally foreign ambassadors writing home, were often unable to interpret it correctly.

There were many very erudite references to the classics, mostly drawn from the compendiums of the learned mythographers, such as Valeriano, which went far beyond the familiar classical allusions that were the stockin-trade in smaller centres: the Nine Muses and Apollo as representatives of the arts, Minerva with her helmet and the Gorgon shield personifying wisdom, Mars for warlike valour and Hercules representing all the virtues associated with the King. The latter included, incidentally, the ability to persuade his listeners with the power of his oratory and not just his physical prowess. This concept, which evolved at the beginning of the century 
Figure de PObelifque : qui

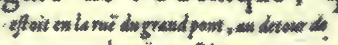

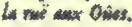

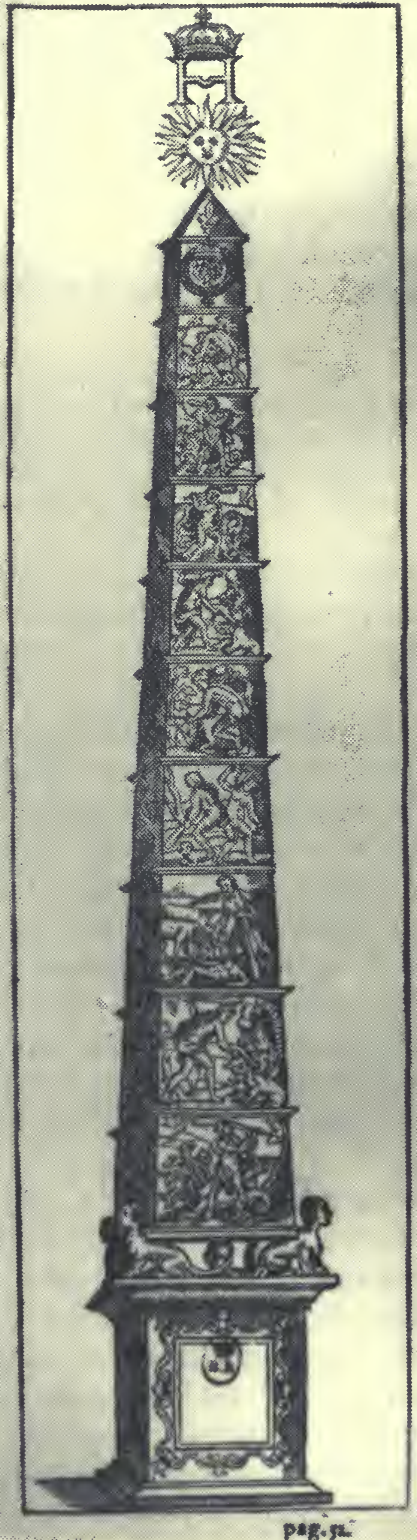

Figure 5: Entry of Henry IV into Rouen, 1596. Obelisk 
when so many classical legends became corrupt, typically shows the monarch with slack chains attached to his tongue leading to the ears of the representatives of the four estates - the nobility, the clergy, the army and the populace. For the 1549 entry into Paris of Henry II, Francis I was shown in this guise on the arch at the Porte St. Denis. (Fig. 4)

If Hercules was the figure most commonly identified with the French kings in the sixteenth century, one can also find examples that provide the transition to the notion of the sun-king that was to dominate the iconography of the reign of Louis XIV. For the obelisk constructed at Rouen for the entry of Henry IV in 1596, for example, the labours of Hercules were shown along with the equally glorious achievements of the monarch, while at the very top of the monument was a large golden sun supporting the King's cipher, an H surmounted by a closed crown. (Fig. 5)

Alastair Fowler and Françoise Joukovsky have examined the notion of triumph or glory in sixteenth century poetry, the one in English and the other in French, and some of their general conclusions apply equally well to the triumphal entry. ${ }^{9}$ Whatever themes were utilized, they all exploited the concept of the king's glory, both individual and hereditary, and after the king's death they evoke the immortality that would be his through an apotheosis similar to that of the Roman emperors.

In the triumphal entry we find substituted for the prosaic daily setting, the decor necessary for the king to become the person he will be in the eyes of posterity. Antiquity was thought to be the true realm of fame or glory, with the present being ennobled through giving to it the dimensions of history. Lasting glory is not just a reflection of material power but a spiritual force, and this glory, as reflected in the triumphal entry, is a feature of merit, not sought in itself but achieved.

\section{University of Toronto}

\section{Notes}

1 For bibliographical information about the entries cited in the text, readers may consult the following: Josèphe Chartrou, Les Entrées solennelles et triomphales à la Renaissance 1484-155I (Paris, 1928); Victor E. Graham, "L'Humanisme lyonnais à travers les entrées triomphales au XVIe siècle" in L'Humanisme lyonnais au XVIe siècle (Grenoble: Les Presses universitaires de Grenoble, 1974), pp. 185-199; George R. Kernodle, From Art to Theatre: Form and Convention in the Renaissance (Chicago: Chicago University Press, 1944); Paul Le Vayer, Les Entrées solennelles à Paris des rois et reines de France, des souverains et princes étrangers, ambassadeurs, etc. Bibliographie sommaire (Paris: Imprimerie nationale, 1896).

2 Bernard Guenée et Françoise Lehoux, Les Entrées royales françaises de 1328 à 1515 (Paris: CNRS, 1968).

3 Jean Jacquiot et Elie Konigson (eds.), Les Fêtes de la Renaissance III (Paris: CNRS, 1975), pp. 187200.

4 George R. Kernodle, From Art to Theatre: Form and Convention in the Renaissance (Chicago: Chicago University Press, 1944).

5 Ralph E. Giesey, The Royal Funeral Ceremony in Renaissance France (Geneva: Droz, 1960). 
6 Hans Peter L'Orange, Studies on the Iconography of Cosmic Kingship in the Ancient World (Cambridge: Harvard University Press, 1953).

7 Marc L.B. Bloch, Les Rois thaumaturges: Etudes sur le caractère surnaturel attribué à la puissance royale particulièrement en France et an Angleterre (Strasbourg: Istra, 1924).

8 John H.A. Sparrow, Visible Words: A Study of Inscriptions in and as Books and Works of Art (London: Cambridge University Press, 1969).

9 Alastair Fowler, Triumphal Form: Triumphal Patterns in Elizabethan Poetry (Cambridge University Press, 1970). Françoise Joukovsky, La Gloire dans la poésie française et néolatine du XVle siècle (Geneva: Droz, 1969). 